\title{
Doing belonging: Meanings of home and settlement among the Karen Community in Brisbane, Australia
}

\author{
Jessica Bird \\ Queensland University of Technology \\ Leonie Cox \\ Queensland University of Technology \\ Mark Brough \\ Queensland University of Technology
}

\begin{abstract}
The phenomenon of belonging allows diasporic people to negotiate socio-cultural terrains that go beyond singular attachments to "here" or "there". This paper interrogates doing belonging amongst members of the Karen refugee community from Burma settling in Brisbane, Australia. We use data collected over twelve months of ethnographic fieldwork using the methods of participant observation and semi-structured interviews. This paper presents an interpretation of challenges faced by Karen community members as they grapple with local and transnational complexities of belonging within their own community, whilst also establishing belonging to Australian social environments. We argue that Karen participants' lived experiences of settlement challenge bounded notions of belonging, thereby allowing us to extend dominant constructions of settlement and social inclusion and give way to a more nuanced representation of an emerging diasporic community. We thus reposition a resettled refugee community away from disempowering and exclusionary notions that dominant constructions of belonging and inclusion tend to impose.
\end{abstract}

Keywords: Karen, belonging, settlement, refugee, transnational

Much of the current political discourse about refugees in Australia reflects a complex terrain of competing voices. One side of this terrain - a more dominant side - tends to vilify people with refugee backgrounds as outsiders to an Australian national identity and as threatening to Australian security (Westoby \& Ingamells, 2010). The Refugee Council of Australia regards such exclusionary negative political discourse as 'the single largest factor in the public misunderstanding of refugees' (2010, p. 93). Take for example the phrase 'Stop the Boats', which provided a common point of political leverage for both primary political parties during the 2013 Australian federal election campaign, as both parties wanted to be seen to be addressing the growing (but relatively small) number of asylum seekers arriving in Australia by boat. This political slogan, as well as the related rhetoric categorising "boat people" as "queue jumpers" and "illegal immigrants" (Hugo, 2002, p. 34), suspends the need for inclusive dialogues oriented toward belonging.

The overwhelming political fixation on border protection sets up a politics of exclusion founded on the protection of "us" from "them". There can be no denying that within this political climate, the stakes are high for refugee communities attempting to belong in Australia.

Corresponding Author: Jessica Bird (Jessica.nancy.bird@gmail.com) 
In this paper, we examine how the Karen go about "belonging" in Australia. Karen people form a minority ethnic group in Burma, involved in civil war against the Burmese government for nearly two-thirds of a century. Many Karen sought refuge in Thailand as a result of this war, and since 2005 were resettled globally (UNHCR, 2010). Australia's 2015 migration programme made 190,000 places available for voluntary migration and 13,750 places for humanitarian and refugee resettlement (DIBP, 2014). It is primarily through the humanitarian migration programme that the Karen arrive in Australia.

The research used in this paper aimed to gain a greater depth of understanding of the lived experience of settlement. This paper presents a fuller picture of that process by switching the focus from more common and abstract discourse, such as settlement policy, to the real practices and events that contribute to processes of belonging for a community experiencing resettlement. We regard doing belonging and belonging work as the daily activities and behaviours that allow the Karen to negotiate tensions of inclusion and exclusion, within their transnational context of "here", "there" or "elsewhere".

\section{Belonging literature}

A significant element of refugee resettlement is belonging work (Skrbiš, Baldassar, \& Poynting, 2007). We explore belonging work for the Karen refugee group as an example of the complexities of settlement faced by forced migrants. The data collected for our research shows their links to their original home are as diverse as their journeys to Australia. Some Karen were born in Burma, and for many decades lived as exiles in the Burmese jungle or in Thai refugee camps before resettling to Australia. Some were born in refugee camps, never knowing their Karen homeland but having nostalgic ties to it through their parents' and grandparents' collective memories. Some Karen were born in Australia, never knowing the camps or Burma, and are forging belonging to the Karen homeland and camps particularly through family left behind. Without meaning to essentialise the Karen's migratory process or represent it in a linear way, there are therefore multiple sites identifiable as home that can contribute to belonging work for Karen in Australia. These include their home Karen village; their places of asylum within Burma but outside of their home village; Thai refugee camps; and Australia. From this perspective alone, belonging work for Karen in Australia is complicated and multi-layered. Thus, the process of "feeling Australian" or feeling at home in Australia is neither simplistic nor linear but characterised by complexity and multiplicity.

The difficulty of neatly theorising belonging (Skrbiš, et al., 2007) adds further to the complexity, given the diversity of migration experiences globally (Klimt 2000, p. 259). Nevertheless, Crisp (2010) describes belonging in terms of connectedness; that the link between belonging and connectedness can demonstrate exclusion and inclusion are not necessarily mutually exclusive processes, but rather overlap. Gifford and Wilding (2013) similarly characterise belonging and social inclusion as an ambivalent landscape. Their research, which focuses on forced migrants, identifies how information and communication technologies (ICTs) can provide alternative sources of belonging for resettled peoples, since ICTs can maintain connection and communication between globally dispersed persons (GDPs). Belonging from their perspective is an active network of GDPs, so that it is about 'becoming at home in a new country' as well as being 'a citizen of a more global, deterritorialized world' (Gifford and Wilding 2013, p. 559).

There is a significant temporal dimension at work here too. Klimt (2000) analysed belonging work for the Portuguese diaspora in Germany using a longitudinal framework. Her research brought to light the changing nature of belonging work over the course of three decades, in conjunction with changing socio-political and economic circumstances. Other research demonstrates the usefulness of specific frameworks in belonging research; Yuval-Davis (2006) used a three-tiered framework of: social locations; identifications and emotional attachments; as well as ethical and political values systems. Antonsich (2010) adapted Yuval-Davis's framework, to focus on place-belongingness (a sense of belonging) as well as 
the politics of belonging. Mason (2007) offers a slightly different approach, by focusing on generational differences to explore belonging. In her research within the Palestinian diaspora, Mason identifies diversity and changes in meanings of belonging associated with different experiences of exile. Thus, rather than generations being identified through more familiar categories of age or migration cohorts (Mason 2007, p. 271), generations are identified 'by what exilic generation they were born into' (Mason 2007, p. 272). The result is that both roots and routes become central to processes of belonging and settlement (see also Lindholm Schulz \& Hammer, 2003, p. 183). Belonging therefore extends beyond the rather restrictive boundaries of citizenship and national belonging into more subjective and blurry spaces characterised by connections, symbolism, and senses. One consequence is that belonging research must recognise the considerable landscape of possibilities involved in belonging work.

This paper adapts Antonsich's (2010) concept of place-belongingness, since we see the value in recognising how belonging intrinsically relates to place. We extend placebelongingness by adding a concept of sense-belonging in order to describe how feelings of belonging can extend beyond boundaries of time and place and into spaces characterised by yearnings, obligations, memories, and political attachments. For instance, histories - as an example of memories - are regarded as a 'necessity of living' in the settlement present (Marlowe, 2011b, p. 63). Histories, understood as memories and attachments to the past, must therefore be acknowledged as being essential to constructions of sense-belonging.

\section{Method}

The ethnographic data used in this paper was collected for a doctoral thesis (fieldwork conducted from February 2011-February 2012). Using participant-observation and ethnographic interviews, the first author collected and recorded thick description of everyday events in the Karen community residing within the greater Brisbane area of Queensland, Australia.

\section{Research approach}

The researcher's aim was to become part of her chosen socio-cultural settings to explore the link between meaning and experience; for instance, by participating in community events she explored the meaning of belonging. Ethnography facilitates such an approach since it has a 'strong emphasis on exploring the nature of particular social phenomena, rather than setting out to test hypotheses about them' (Atkinson \& Hammersley, 1994, p. 248). Ethnography also tends to focus on a smaller number of cases, works with unstructured data, and interprets meanings of human actions using descriptive language, rather than relying on quantifiable or statistical information (p. 248).

\section{Data collection}

The eleven months of fieldwork conducted in Brisbane included attending many community events, church services, and local meetings. This method of participant-observation allowed interaction with people in their daily lives to gain an emic understanding of the settlement experience (O'Reilly 2005, p. 84), and was supplemented by 35 ethnographic interviews conducted in English (a substantial proportion of this community can converse in English). Fieldwork also included attendance at a Sydney forum for 18 Karen community leaders from around Australia, who gathered to formulate a Karen settlement strategy. Here, the researcher was primarily an observer and afterwards conducted interviews.

The final month of fieldwork in Thailand, mainly on the Thai-Burma border, used participantobservation and ethnographic interviews as data collection methods. Meetings with Karen organisations and a refugee policy-building organisation in Bangkok - the Thai Committee for Refugees Foundation (TCR) - were to gather insight into the Brisbane diaspora outreach and 
network. Together, these experiences provided the possibility to consider the dynamics of belonging for a group no longer at home in Burma.

\section{Data analysis}

All fieldwork was recorded using field notes, and data analysed concurrently. The process allowed for both inductive and deductive modes of analysis so that the data could unfold to tell its own story. This iterative approach, known as recursive or grounded analysis, is useful in ethnographic work as it can help 'to find an explanatory framework between the particular and the general' (Madden, 2010, p. 18), and to guide enquiries or questions whilst the events are in play.

\section{Ethics}

The primary participant group included people from the Brisbane Karen community and others elsewhere in Australia and Thailand (inclusive of people not of Karen ethnicity). Ethical approval was granted for this research by the Queensland University of Technology's Research Ethics Committee (approval number 1100000189), which in particular allowed for research with people from refugee backgrounds, as well as young participants. All participants' names are replaced with Karen pseudonyms for confidentiality, and some participants' stories are further de-identified due to profound fear of socio-political ramifications.

\section{Karen Community in Brisbane}

No census data records the number of people in Australia that identify as Karen ethnicity, as the Australian Bureau of Statistics records people's country of birth, rather than ethnic group. Personal estimations from a prominent Karen community leader in Brisbane, however, place the number of Brisbane Karen between 750-1000, and over 7000 live in other major Australian cities (personal communication, Par Do, 15/9/2010).

The primary participant group numbered 40 for this study. Participants' ages ranged from 13 to 70 years old and the genders about equally represented. At the time of the research, a majority of interviewees had lived in Australia for three to six years. Most migrated with their families - typically three generations - meaning that in the community, some were born in Burma, some in refugee camps, and others in Australia. Such differences are important to make explicit since these multiple pathways to life in Australia - including religious identifications - impact on feelings of belonging.

Anecdotal evidence from participants describes how a high proportion of Brisbane Karen, and the globally resettled Karen community, identifies strongly with Christianity (see also Rangkla, 2013). This is because Christianity is a primary characteristic for persecution in Burma and has forced many into displacement and migration. Consequently, a majority of Karen remaining in Burma identify with Buddhism, not Christianity, since Buddhists do not experience religious persecution (Rangkla, 2013). The evident commitment of many Australian Karen to Christianity is of particular significance for feelings of belonging, since their strong faith in the church takes boundaries of belongingness into spiritual spaces that are not necessarily bound by place (Burma).

\section{Results}

\section{Feeling here, there and elsewhere: sense-belonging}

The challenge of belonging for the Karen is only in part one of belonging in Australia. Belonging work takes place on multiple fronts, not least, here, there and elsewhere. Although we have already made use of the terms here and there in this paper, these terms are problematised by the experience of forced displacement and resettlement. The apparent dichotomy between here and there characterises a sense of closeness and distance, to and 
from, adopted and traditional homelands (Hamaz \& Vasta, 2009). However, an examination of how the Karen in this study experienced settlement makes clear that here and there are not always congruent with their assumed characteristics; rather, in direct opposition, here can be quite distant and there much closer.

For example, Saw Eh, a middle-aged Karen man who has lived in Australia since 2008 without any family, described how his original homeland sits heavily in his heart; even after three years of living in Australia he could not connect with this new homeland, usually considered to be here. He said, 'If I had a bicycle, and there was no water, I would ride all the way home' [to Burma] (pers. comm. 17/09/2011). Saw Eh's longing to be home makes it difficult to develop feelings of belonging to a new home; thereby rendering here, the space to which one feels close, as distant. Consequently, the distance and alienation felt towards his current geographical location gives it the flavour of being there in terms of sensebelongingness, although it is physically close. Any attempts to connect emotionally with the physical here are more difficult since his socio-cultural and linguistic isolation complicate the simplest tasks such as taking transport. As Par Bor Tho, the secretary of the Australian Karen Organisation, described, 'People from refugee camps have never seen things; they can't speak or write (English]... It is very confusing for them, especially catching the bus' (pers. comm. 17/09/2011). For this man, doing belonging in the new locale is complex, since his strong sense of belonging to an elsewhere place, coupled with feelings of local exclusion, are competing with efforts to establish belonging to a new home.

Furthermore, since belonging is often regarded as an active set of relationships (Gifford \& Wilding, 2013; Noble, 2007), the diasporic elsewhere must also be acknowledged as instrumental in belonging work and to feeling at home. Take, for example, the story of Naw Lar. Naw Lar is a 30-year-old Karen woman, and at the time of fieldwork had lived three years in Brisbane with her sister and friends. Her fiancé resettled in America, and her parents and extended family resettled to rural Queensland. Naw Lar carries with her considerable emotional attachment and financial obligation to her homeland, but informal conversation demonstrated that she also considers her feelings of home split between her disparate families. At the time of research, Naw Lar's fiancé was struggling to get a visa to Australia, and as such, Naw Lar was considering America as a place for secondary migration. For Naw Lar, "there" is not her original homeland, the Thai camps, nor her resettled families, but all of them, simultaneously. Within the onto-spatial imagination of the Karen the "diasporic elsewhere" becomes a site for (re)building disparate global connections and relationships. The concept of the diasporic elsewhere is useful here since it questions the apparent and assumed dichotomy of "here" as opposed to "there" constructions. Since families, social networks and religious communities are considered central to diasporic Karen social life (Worland \& Darlington, 2010) and these relationships are stretched globally through resettlement, a sense of belonging can be elsewhere, here and there all at the same time.

We argue, therefore, that exclusively locating sense-belonging here or there or elsewhere is simplistic, and denies the intersubjective, constructed and strategic nature of belonging and identity. The following example reinforces this point. A Karen phrase (te kaw) describes how a Karen person can feel at home, or belonging to Karenness, despite being away from the original homeland. A Karen elder in Brisbane, Par Bu was once a village leader in the Karen state, then driven into the jungle for two decades with his family before being resettled with his family to Brisbane in 2006. He explained belonging this way: 'te' (water) and 'kaw' (land or country) 'is the country you are standing at the moment - this [kaw] is your land' (pers. comm. 13/08/2011). Home, or te kaw, is not constituted by place but by a sense of belonging to both Karenness and to Karen groups. This sense-belongingness demonstrates how "here" can stretch transnationally.

The story of a 28-year-old Karen man, Par K'Saw, provides another example. He moved in 2007 from a Thai refugee camp to Brisbane without his family. Since 2009 he has been 
serving in the Australian Defence Force. Par K'Saw said that whilst he is Karen, he also considers himself Australian - not because he militarily represents Australia but because he lives in the country. For him, sense-belongingness and place-belongingness are intrinsically related. After our interview, Par K'Saw shared the following comment with his predominantly Karen network on social media: 'if home is where the heart is, what happens when yours is torn in two?' (pers. comm. 21/8/2012). Clearly, the dynamics of politics and place also add complexity to a person's emotional sense of belonging at home.

This complexity is lost in the language of "host society" (see for example Ager \& Strang, 2008) or "receiving society" (see for example Schwartz, Pantin, Sullivan, Prado, \& Szapocznik, 2006). We contest the simplistic inference of such terms where the settling group has no agency and is conceptualised as passive recipients of services provided by the host. Whilst settlement agencies provide important and strategic services to settling groups, there is more to doing settlement than can be addressed by them. There are numerous examples of Brisbane Karen people meeting their own needs in settlement; such as through the services provided by the Australian Karen Organisation (AKO) and the Logan City Karen Community (LCKC) - both providing practical settlement support for local Karen.

\section{Kanga Karen: language, food and sense-belonging}

The Karen take particular pride in their language and food (amongst many other features of Karen cultural expression that are beyond the capacity of this paper). These two powerful symbols of identity deserve special attention in terms of belonging. We turn first to the issue of language, which is particularly interesting since historically there have been 15 dialects and two forms of Karen language recorded (Sadan, 2008), and in contemporary Burma, a majority of Karen speak Pwo Karen. Most Karen in Brisbane, however, use Sgaw Karen, the language predominantly spoken by Christian Karen in Burma. A small majority of the Brisbane community speak Pwo Karen. Many also speak English, Thai and/or Burmese. The link between language and Karen identity is consequently a complex one, since at home and abroad, language as a marker of identity can be understood differently. For example, a 30-year-old Karen woman Naw Bleh, who resettled with her family to Brisbane in 2006, described her belonging to Australia in terms of language: 'I am not feeling Australian in any way. I only speak Karen at home' (pers. comm. 10/9/2011).

Language as a marker of identity is made more complex, when language and food are considered together. There are, for example, some Karen who speak English and eat "Australian" food, who are considered as threatening to Karen identity. As Par Nya, a Karen community leader and father of three explained with concern:

Our children eat here and are growing up in Australia. They eat Australian food, and don't want to eat rice. It definitely puts our identity into question. They are Kanga Karens - speak Karen but with Australian accents! (pers. comm. 1/10/2011)

The evocative term Kanga-Karen is one commonly used in the community to demarcate young Karen born in Australia. Par Nya's next statement elaborated the point: 'When we arrive we are Karen, then soon we are Karen-Australian. When our kids are born here they are Kanga Karens!'

Among the Karen, language takes on both practical and symbolic significance as a form of communication and as a marker of identity. Language, as a cultural practice from the homeland, can therefore construct a sense of belonging and draw boundaries around membership, which includes those who speak Karen, and identify as Karen. Yet constructions of belonging in the new homeland continue to reflect the complex array of Karen languages in the original homeland; consequently, at community events the many languages spoken in Brisbane (including Sgaw Karen, Pwo Karen, Burmese, Thai, and English) are considered. This sort of language negotiation must account for the 
practicalities of communication, but also the symbolic meaning facilitated by the use of one language in preference to another.

The complexity of language and identity evident amongst the Karen challenges simplified, ahistorical, generic renditions of cultural homogeneity often favoured in public discourse and reflected in the institutionalised dialogue of services for newcomers to Australia. For example, some Karen in Brisbane describe being offered Burmese-speaking interpreters by service providers, even though many of them cannot speak Burmese. The AKO often deals with such settlement issues. The AKO formed in 1996 as a lobby group, but since then has evolved to act as a social, cultural and economic organisation that, amongst other things, ensures their Karen people in Australia are positively engaging with settlement. Par Bor Tho, the Secretary for the AKO, explained: '[We] advocate [for] interpreters. 70\% of Karen can't speak Burmese and we always get given them for interpreters - so we make sure we try to get Karen and not Korean or Burmese' (pers. comm. Par Bor Tho, 17/9/2011). He spoke of examples where this led to problems: 'One woman had a water bill and was given a Burmese interpreter - she signed everything because she didn't understand and paid too much for her bill.' He continued:

Our community experienced a very bad experience. One family was forced to leave their accommodation in 2008 - a Burmese interpreter said they had to leave - they had signed for six months and it was only five months so they didn't understand.

This complexity of language includes a deeper political dimension too, since many Karen are unwilling to access or give information to Burmese-speaking interpreters because this is the language of their oppressors in Burma. Despite the Karen having been engaged in civil war with the Burmese military for over half a century, the Karen are often considered "Burmese" by over-simplified Australian institutional logic. Fears that Burmese national spies are operating in the Karen diaspora add further tension to this politics of language. As one young Karen woman Naw Pay commented, the Burman-Karen relations in Brisbane are causing intra-community tension, and 'they shouldn't be too close - I don't trust it and [the Burmans] are getting too close' (pers. comm. 2/2/2012). Issues around language therefore have implications for the participants' emotional wellbeing and their sense of identity and belonging, beyond the instrumental act of learning English to communicate.

We now turn to food as an instrument in Karen belonging work. Whilst rice is a staple of traditional Karen diets and is typically served at every meal, one Brisbane Karen mother and a leader of the small Buddhist community, who has lived in Brisbane since 2007, Naw Eh, commented that since the Karen's 'main food is rice', if they only have rice to eat, they would survive:

They help the refugee with food so we can survive with the support of them. But it was not enough, but we can survive with the rice because our main food is rice, we can survive' (pers. comm. 17/10/2012).

Naw Eh's statement comments on the central role played by rice in Karen livelihoods in Burma and Thailand (Bird, Brough, \& Cox, 2016), but Par Bu, the Karen elder and village leader in Burma, also explained the significance of rice as an everyday symbol of Karen identity: 'Rice - before it is cooked, it is one by itself. After cooking it, it is squished together. Every time you eat rice you remember your people and who you are'. For Par Bu, rice is a powerful symbolic material that can reinforce identity work and belonging throughout the Karen every day. Par Do, a community leader and father of four children (one of which was born in Australia), also described how food for Karen is 'Rice, rice, rice, and jungle veges'. He continued, that in the diaspora Karen people must be reminded of the importance of food in their cultural practice: 'Hospitality is a big thing - even strangers we prepare food for - we have to remind our people to maintain this' (pers. comm. 10/1/2012). The centrality of food 
as both a staple and social mechanism is evident, and can consequently form an essential part of belonging work in settlement, since it acts as a daily reminder of what it means to "be Karen" in a new social space.

Karen food, and particularly rice, has symbolic meaning that goes beyond representing continuity in the context of Karen everyday life. As Naw Eh's description demonstrates, rice is a marker of individual Karen selfhood but also demonstrates belonging to a collective identity. Food can help establish an 'embodied relationship with home' (Taylor, 2013, p. 151) and therefore needs to be acknowledged as an everyday tool in belonging work. It was also evident during fieldwork that food-based belonging work is complex for Brisbane Karen, in terms of access, provision and preparation. Many must negotiate access to Karen food as well as new technologies used to prepare it. A number of Karen travel enormous distances to buy familiar food for their families. In response, Michael, a non-Karen man who was highly active at the church where many Karen visit, set up the Brisbane Community Aid shop that sells Asian and Karen foodstuffs (amongst other things) to the northside Karen and other disadvantaged groups. A Karen volunteer at the shop said, 'Before [he set up the $\mathrm{BCA}$ ] we would take a whole day to drive from northside to Inala (south Brisbane) to get Asian food.'

Newly arrived Karen described other significant challenges in their food practices. Food packages provided for newly settling Karen did not have rice, or enough rice for their families. Nor were the new arrivals familiar with the technology provided to cook the food. Par Bor Tho, who advocates for services for his Brisbane community through the AKO, said: 'Karen people eat rice, not bread, tomato sauce, vegemite. They used to not give a rice cooker but now they do because we asked them to, but the people don't know how it works. They also give a family of five the same size cooker as a family of ten.' Naw Lar described how one family was left in a motel on arrival without instructions on how to use the technology: 'Another family [was] in [a] motel for 24 hours and left [by the case worker] with one pod of rice, bread and milk and not told them how to turn on the oven' (pers. comm. 14/08/2011). Naw Eh, a 47 year old and mother of four told how her family also had difficulties with food preparation when they first arrived in Australia:

When we got to Chifley Hotel, we were very hungry. But, we don't know how to cook because our rice cooker that we brought with us didn't fit the plug, because we lived in hotel we haven't got the household material, but we have brought some cooker from Thailand. So, after a few days my friend gave me a plug for our rice cooker... I was very glad to see the green apple [they gave us], I thought it was not very big, and green, like the plum in Thailand and I thought "I like that one" so I bite into it and it very sour! (laughs). And then I realised it is not the same. And they give me the orange and we have to wait a long time to go into the motel and we wait in the car for the case worker for one or two hours. And I tried to peel the orange and I couldn't 'cause they were hard ones [When they moved us] to Coburg, the driver registered us and this time [gave] only a small bag of rice [for] eight people. And we thought what should we do? No one came and supervised. (pers. comm. 17/10/2012).

Naw Lar's, Naw Eh's and Par Bor Tho's experiences all point to the importance of food in belonging work, and more generally, the problems encountered in food provision and preparation mirror the complexities of settlement. Moreover, it is important to acknowledge that the importance of Karen food goes beyond simply being a familiar cuisine. Many Karen have farming backgrounds; hence, they also in particular highly value the productive symbolism of rice. 


\section{Group membership and sense-belonging}

We now focus on the notions of relationships and memberships in constructing a sense of belonging. Skrbiš, Baldassar and Poynting (2007, p. 262) argue that belonging can be understood as 'a set of processes that are central to the way in which human relationships are conducted'. Consequently, people are 'caught up in a continuing and dynamic dialectic of seeking and granting belonging' through formal and informal politics of boundary making (Skrbiš et al. 2007, p. 262). The process of seeking and granting belonging, which is also evident amongst Australian Karen, thus brings into question modes of inclusion and exclusion in group memberships and networks. Some belonging work therefore requires boundaries around membership so that rights to belonging can be established beyond nationalistic assumptions of citizenship. Belonging work is taken to another level here since boundary dynamics can cause friction and fragmentation in the community.

The AKO is an incorporated organisation very much involved in Karen belonging work. The AKO is a national body with state branches providing social, cultural and settlement support to the Karen. It is also a branch of the Karen National Union (KNU), which is a proxy government for the Karen state in Burma. Hence, membership of the AKO has symbolic power, and use of its services has symbolic implications. It intangibly links, for example, Brisbane Karen with the KNU's military programs and its transnational nationalistic movement. For some, therefore, participation with the AKO symbolises support of the civil war in Burma. The AKO also links Brisbane Karen people with the global diasporic Karen community, via the KNU's transnational networks. Participation in community events run by the AKO thus often involves transnational identity work and informal membership in the global pan-Karen network of alliances.

However, membership of this organisation raises considerations of the politics and memory of conflict. As such, some Brisbane Karen choose to exclude themselves from participation with the AKO. Take for example a middle-aged Karen man's comment, who said he wishes to denounce all ties with the KNU after being resettled in Australia: 'All my life I have been shot at by the Burmese or living in politics and I just want peace and quiet here' (pers. comm. 10/1/2012). The AKO's political activity raises a difficult consideration for some Karen to reconcile. They feel a duty to remember their homeland and support those remaining, yet also a desire to leave the conflict in Burma. Equally, the AKO must then reconcile the desires of the local diaspora with its commitment to the KNU. This friction adds yet another layer to belonging in settlement. It demonstrates how belonging work involves complex acts of negotiation on multiple fronts.

We must also take note here of the value of church membership for Karen sensebelongingness. As discussed earlier, a majority of the resettled Karen population identifies with Christianity. Certainly, during fieldwork in Brisbane and Thailand, the Christian Karen communities displayed deep religious commitment to their church, and a distinct spiritual connectedness between them was evident. This connectedness extended local networks via connections to their Christian communities in the homeland, the camps, and the diaspora. Such widespread connection was further evident at large-scale international gatherings for young Christian Karen (held often in Thailand) and in global efforts to raise funds for their counterparts still amidst war in Burma. Membership of such spiritual groups can render belonging as a sense of spirituality, thereby also rendering notions of home transient and more personal. Belonging, therefore, is reinforced by participation in the farreaching Christian Karen network, which extends from the local Christian Brisbane Karen community into much broader, local and global ones. 


\section{Discussion}

\section{"Successful Settlement" and belonging work}

This study demonstrates the dynamic, contextual and personal nature of sensebelongingness in settlement. Such complex intersubjective understandings of settlement and belonging compete with nationalistic conceptions, which tend to focus on managing pathways to "successful settlement". To this end, government policy requires settlement agencies and mainstream services to monitor the settlement outcomes of humanitarian entrants under a rigid set of characteristics. For example, governments articulate processes of settlement (such as gaining meaningful employment) through policy as outcomes and goals and heavily judge settlement in these concrete terms. However, we argue that successes in settlement can and need to be articulated through belonging work such as maintaining important practical and emotional connections to food, language, people, places and spirituality (Fozdar \& Hartley, 2013).

As the Refugee Council of Australia (RCOA) - a non-government organisation - explains, several measurable factors can demonstrate an established point of settlement. These include 'income support, housing, employment, education, health care and family reunion' (Refugee Council of Australia, 2011). However, there are more complex processes that must also be acknowledged as seeking to fulfil essential goals in settlement, including: safety and security; reinforcing a sense of identity, self-worth and dignity; regaining control; and developing life skills to cope with feelings of guilt and loss (Refugee Council of Australia, 2011). Indeed, some participants in RCOA's research commented on how they regard the most important feature of "reaching successful settlement" as feeling socially included (Refugee Council of Australia, 2010, p. 90). Their perspective underlines the importance of belonging. The RCOA recommended the establishment of a nationally recognised "successful settlement" framework that includes 'uniform eligibility criteria, settlement service standards and measures of successful outcomes applied across the full network of services' (Refugee Council of Australia 2010, pp. 64-65). Our findings suggest that such a framework should acknowledge the complexities that go with belonging.

In short, this ethnography supports Hamaz and Vasta's (2009, p. 13) argument that the "transnational bridging and the inter-connectedness of "here" and "there"...has added another layer to the notions of belonging and commitment across national borders'. Multiplicity is central to belonging work since belonging to numerous, dynamic and overlapping spaces requires the Karen to respond to here, there and elsewhere. The Karen's complex onto-spatial imaginings of settlement problematizes reductionist and linear constructions of settlement. Belonging is not only a matter of feeling "at home" here, but also encompasses an ongoing negotiation of transnational attachments and local expectations of integration, amidst the structural limitations of the lived environment. Marlowe (2011a, p. 64) argues that these circumstances require a 'more nuanced understanding of the dynamic cultural, social and political exchanges between numerous players as these horizons intersect'. Therefore we endorse Marlowe's call 'to look beyond basic assumptions' that limit the perceptions of people with refugee backgrounds within bounded categories and instead construct a 'dialogue rather than essentialised monologues' about people experiencing these journeys (Marlowe, 2011b, p. 64).

\section{Conclusion}

An exploration of the multiplicities that characterise the belonging work of Brisbane Karen demonstrates how context, experiences of inclusion and exclusion, as well as the politics of language and food, impact on how people construct a sense of belonging to place. Belonging is not a straightforward process for Brisbane Karen, who live in a context where attachment, roots and rootedness, politics, commitment, and memberships are all contested. 
These complex dimensions of belonging continue to raise other questions about home and its relation to here, there and elsewhere, as well as how people manage to reconcile these seemingly disparate places in conditions of displacement, exile and global resettlement. Much of the dominant xenophobic political discourse we referenced at the beginning of this paper centres on an assumption of "outsiders" not wanting to "fit in". Yet, our findings here show enormous motivation, activity and sophistication among Karen as they tackle the challenging task of belonging.

Moreover, the experiences of the Karen in this study attest to the need to confront limiting discourses that frame people from refugee backgrounds as victims, and instead acknowledge and celebrate their capacity to be 'actors in their own lives' (Taylor, 2013, p. 135) - as people with agency and a right to self-determination within their new socio-cultural surrounds (Gifford \& Wilding, 2013). 


\section{References}

Ager, A., \& Strang, A. (2008). Understanding Integration: a Conceptual Framework. Journal of Refugee Studies, 21(2), 166-191.

Antonsich, M. (2010). Searching for Belonging - An Analytical Framework. Geography Compass, 4(6), 644-659. doi: 10.1111/j.1749-8198.2009.00317.x

Atkinson, P., \& Hammersley, M. (1994). Ethnography and Participant Observation. In N. Denzin \& Y. Lincoln (Eds.), Handbook of Qualitative Research (pp. 248-261). Thousand Oaks: Sage Publications.

Bird, J. N., Brough, M., \& Cox, L. (2016). Transnationalism and the Karen wrist-tying Ceremony: An ethnographic account of Karen settlement practice in Brisbane. The Australian Journal of Anthropology, 27, 104-120.

Crisp, B. R. (2010). Belonging, Connectedness and Social Exclusion. Journal of Social Inclusion, 1(2), 123-132.

DIBP. (2014). Fact Sheet 20 - Migration Programme Planning Levels, 2014

Fozdar, F., \& Hartley, L. (2013). Civic and Ethno Belonging among Recent Refugees to Australia. Journal of Refugee Studies, 1-19.

Gifford, S. M., \& Wilding, R. (2013). Digital Escapes? ICTs, Settlement and Belonging among Karen Youth in Melbourne, Australia. Journal of Refugee Studies, 26(4), 558575.

Hamaz, S., \& Vasta, E. (2009). '"To Belong Or Not to Belong": Is that the Question?' Negotiating Belonging in Multi-ethnic London. Working Paper. Centre on Migration, Policy and Society, University of Oxford. Oxford.

Hugo, G. (2002). From Compassion to Compliance? Trends in Refugee and Humanitarian Migration in Australia. GeoJournal, 56(1), 27-37. doi: 10.1023/a:1021752802043

Klimt, A. (2000). European Spaces: Portuguese Migrants' Notions of Home and Belonging. Diaspora: A Journal of Transnational Studies, 9(2), 259-285.

Lindholm Schulz, H., \& Hammer, J. (2003). The Palestinian Diaspora: Formation of Identities and Politics of Homeland: Psychology Press.

Madden, R. (2010). Being Ethnographic: A Guide to the Theory and Practice of Ethnography: Sage Publications Ltd.

Marlowe, J. M. (2011a). Sudanese Settlement: Employing Strategies of Intercultural Contact and Cultural Maintenance. Australasian Review of African Studies, 32(2), 101-117.

Marlowe, J. M. (2011b). 'Walking the Line': Southern Sudanese masculinities and reconciling one's past with the present. Ethnicities, 12(1), 50-66.

Mason, V. (2007). Children of the "Idea of Palestine" 1: Negotiating Identity, Belonging and Home in the Palestinian Diaspora. Journal of Intercultural Studies, 28(3), 271-285. 120

Noble, G. (2007). Respect and Respectability Amongst Second-generation Arab and Muslim Australian Men. Journal of Intercultural Studies, 28(3), 331-344.

O'Reilly, K. (2005). Ethnographic Methods: Routledge.

Rangkla, P. (2013). Refuge and Emplacement through Buddhism: Karen Refugees and Religious Practices in a Northwestern Border Town of Thailand. The Asia Pacific Journal of Anthropology, 14(1), 8-22.

Refugee Council of Australia. (2010). Australia's Refugee and Humanitarian Program 20102011: Community Views on Current Challenges and Future Directions. Retrieved from http://www.refugeecouncil.org.au/r/isub/2010-11-IntakeSub.pdf

Refugee Council of Australia. (2011). What does 'settlement' mean? Retrieved 01/06/2014, 2014, from http://www.refugeecouncil.org.au/f/smt.php

Sadan, M. (2008). A Guide to Colonial Sources on Burma: Ethnic \& Minority Histories of Burma in the India Office Records, British Library. Bangkok: Orchid Press.

Schwartz, S. J., Pantin, H., Sullivan, S., Prado, G., \& Szapocznik, J. (2006). Nativity and Years in the Receiving Culture as Markers of Acculturation in Ethnic Enclaves. 
Journal of Cross-Cultural Psychology, 37(3), 345-353. doi: 10.1177/0022022106286928

Skrbiš, Z., Baldassar, L., \& Poynting, S. (2007). Introduction - Negotiating Belonging: Migration and Generations. Journal of Intercultural Studies, 28(3), 261-269.

Taylor, H. (2013). Refugees, the State and the Concept of Home. Refugee Survey Quarterly, 32(2), 130-152. doi: 10.1093/rsq/hdt004

UNHCR. (2010). Myanmar: 2011 UNHCR Country Operations Profile. Retrieved from http://www.unhcr.org/cgi-bin/texis/vtx/page?page=49e4877d6

Westoby, P., \& Ingamells, A. (2010). A Critically Informed Perspective of Working with Resettling Refugee Groups in Australia. British Journal of Social Work, 40(6), 17591776.

Worland, S., \& Darlington, Y. (2010). The Identity of Displaced Christian Karen in the Context of Resettlement. Asia Pacific Journal of Social Work and Development, 20(1), 16-28.

Yuval-Davis, N. (2006). Belonging and the Politics of Belonging. Patterns of Prejudice, 40(3), 197-214.

\section{Biographical notes}

Jessica Bird is a social anthropologist with experience in working with refugee and Pacific Islander communities, including the Karen diaspora, the Samoan diaspora and indigenous communities in New Caledonia. Her research focuses on processes embedded within the transnational and translocal lived experiences of minority groups.

Leonie Cox is a medical and social anthropologist whose ethnographic work with Aboriginal and Torres Strait Islanders has an emphasis on the intersection of colonial history, contemporary policy and practice, knowledge, power, class, race relations and well-being. Leonie also has extensive clinical experience in the mental health field and she teaches and publishes on the relationship between culture and health. Her take on this relationship embraces the philosophy of cultural safety promoting a social justice approach to working with marginalised people.

Mark Brough is a social anthropologist with extensive experience in cross-cultural research and teaching. Mark specialises in the application of cross-cultural understanding to a wide range of health contexts. He has worked with diverse communities including Aboriginal and Torres Strait Islander, refugee, migrant, urban and remote. He has particular expertise in the social determinants of health and wellbeing and in the role of human service and health professionals in addressing those determinants. 